Thorax (1968), 23, 434.

\title{
Endometriosis of the lung A case report and brief review of the literature
}

\author{
TATIANA JELIHOVSKY ANDA. F. GRANT
}

From the Department of Pathology and the Page Chest Pavilion, Royal Prince Alfred Hospital, Camperdown New South Wales, Australia

A case is described of endometriosis of the lung in a symptomless 54-year-old woman. This and the 11 previously recorded cases of histologically examined pulmonary endometriosis have been divided into two groups. Six of these women had died during pregnancy or shortly after delivery, and their lungs contained deposits of decidua but no endometrial glands; the remaining six patients, at least five of whom had had previous pregnancies, had surgically resected lung specimens showing larger single lesions with endometrial glands. The possible relationship between these two groups is discussed.

Endometriosis of the lung is rare. Although the condition has been diagnosed clinically in patients with a history of recurrent catamenial haemoptyses, a search of the literature revealed only 11 cases in which endometrial tissue was found on histological examination of the lungs. These fell into two distinct groups. In the first, small islands of decidua were found at necropsy in the lungs of six subjects who had died either during pregnancy or shortly after delivery (Table I). In the second, larger single lesions with endometrial glands were found in surgically resected specimens (Table II).
One of these was from a post-menopausal womar (Sturzenegger, 1960), and it is the purpose of this paper to present a second such case.

\section{CASE HISTORY}

A 54-year-old woman, born in Hungary but living in Australia during the past eight years, was found ou mass miniature radiography to have a shadow in the. right lung and was referred for further investigation She gave a history of exertional dyspnoea for the past few years, during which she had gained weight. At the time of examination her weight was $200 \mathrm{lb}$. $(90.7 \mathrm{~kg}$.

T A B L E I

DECIDUA FOUND IN THE LUNG AT POST-MORTEM EXAMINATION

\begin{tabular}{|c|c|c|c|}
\hline Author & Time of Death & Lung & Remarks \\
\hline Park (1954) & 4 hours after delivery & $\begin{array}{l}\text { One focus of decidua } 250 \mu \text { across, } 6 \mathrm{~mm} \text {. beneath the pleura, } \\
\text { not lying in blood vessels and with no evidence of a large } \\
\text { vessel having been eroded. Large capillaries within and at } \\
\text { margin of plaque }\end{array}$ & \\
\hline$\overline{\text { Hartz (1956) }}$ & & & 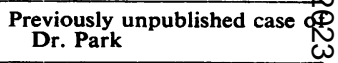 \\
\hline Hartz (1956) & 4th month of pregnancy & $\begin{array}{l}\text { One focus of decidua } 500 \mu \text { across, lying directly beneath the } \\
\text { pleura. In one section a thin-walled vessel was seen } \\
\text { between the cells }\end{array}$ & \\
\hline $\begin{array}{l}\text { Lattes et al. } \\
\quad \text { (1956) }\end{array}$ & During delivery & $\begin{array}{l}\text { Multiple small clusters of decidual cells apparently emboliz- } \\
\text { ing capillaries of the interalveolar septa }\end{array}$ & $\begin{array}{l}\text { Previously unpublished case } \bar{\Phi} \\
\text { Dr. Godman similar to that } \\
\text { reported by Dr. Hartz }\end{array}$ \\
\hline $\begin{array}{l}\text { Cameron and } \\
\text { Park (1965) } \\
\text { Case } 1\end{array}$ & After delivery & $\begin{array}{l}\text { Multiple islands of decidua up to } 580 \mu \text { across, well estab- } \\
\text { lished and growing in the walls of blood vessels and } \\
\text { alveoli }\end{array}$ & $\vec{D}$ \\
\hline $\begin{array}{l}\text { Cameron and } \\
\text { Park (1965) } \\
\text { Case } 2\end{array}$ & $\begin{array}{l}\text { 35th week of pregnancy; } \\
\text { undelivered }\end{array}$ & $\begin{array}{l}\text { One plaque of decidua } 300 \mu \text { across, lying } 5 \mathrm{~mm} \text {. beneath } \\
\text { the pleura }\end{array}$ & \\
\hline
\end{tabular}


T A B L E I I

ENDOMETRIAL GLANDS FOUND IN RESECTED LUNG SPECIMEN

\begin{tabular}{|c|c|c|c|c|}
\hline Author & $\begin{array}{l}\text { Reproductive } \\
\text { Status }\end{array}$ & Past History & Presenting Features & Lung Lesion \\
\hline $\begin{array}{l}\text { Lattes et al. } \\
\quad(1956)\end{array}$ & Pregnant & $\begin{array}{l}\text { Caesarean and curet- } \\
\text { tage }\end{array}$ & $\begin{array}{l}\text { Cyclical haemoptyses following curet- } \\
\text { tage. Radiographic shadow became } \\
\text { obvious during last pregnancy }\end{array}$ & $\begin{array}{l}\text { Nodule of decidua and endometrial } \\
\text { glands, } 18 \mathrm{~mm} \text {. diam., with a poly- } \\
\text { poid projection into bronchus }\end{array}$ \\
\hline $\begin{array}{l}\text { Sturzenegger } \\
(1960)\end{array}$ & Post-menopausal & $\begin{array}{l}\text { Panhysterectomy at } \\
\text { age } 46\end{array}$ & Radiographic opacity & $\begin{array}{l}\text { Cyst, } 4 \mathrm{~cm} \text {. diam., lined by endomet- } \\
\text { rium with a polypoid projection }\end{array}$ \\
\hline $\begin{array}{l}\text { Rodman and } \\
\text { Jones (1962) }\end{array}$ & Pre-menopausal & Abortion & $\begin{array}{l}\text { Cyclical haemoptyses following abor- } \\
\text { tion. Radiographic opacity appearing } \\
\text { only at time of haemoptysis }\end{array}$ & $\begin{array}{l}\text { Mural nodule of endometriosis pro- } \\
\text { jecting into bronchiole and contain- } \\
\text { ing a branch of a bronchial artery }\end{array}$ \\
\hline $\begin{array}{l}\text { Mobbs and } \\
\text { Pranner } \\
\text { (1963) }\end{array}$ & Pregnant & $\begin{array}{l}\text { Pregnancy terminated } \\
\text { by surgical induc- } \\
\text { tion at } 20 \text { weeks }\end{array}$ & $\begin{array}{l}\text { Radiographic opacity during } 2 \text { nd preg- } \\
\text { nancy. No cavitation }\end{array}$ & $\begin{array}{l}\text { Nodule of decidua and endometrial } \\
\text { glands, } 2 \cdot 5 \mathrm{~cm} \text {. across }\end{array}$ \\
\hline $\begin{array}{r}\text { Kovarik and } \\
\text { Toll (1966) }\end{array}$ & Pre-menopausal & Gravida 3, para 3 & $\begin{array}{l}\text { Recurrent pneumothorax occurring } \\
\text { during first } 2 \text { days of menstrual } \\
\text { period. Began after birth of first } \\
\text { child }\end{array}$ & $\begin{array}{l}\text { Collapsed cysts lined by low cuboidal } \\
\text { epithelium similar to that in the } \\
\text { endometriotic lesion of the dia- } \\
\text { phragm. The pulmonary lesion is } \\
\text { not in itself diagnostic of endo- } \\
\text { metriosis }\end{array}$ \\
\hline Present case & Post-menopausal & $\begin{array}{l}\text { Normal deliveries } 35 \\
\text { and } 14 \text { years pre- } \\
\text { viously }\end{array}$ & Radiographic opacity & $\begin{array}{l}\text { Thin-walled cyst with polypoid projec- } \\
\text { tion }\end{array}$ \\
\hline
\end{tabular}

There was no history of cough, haemoptysis, or chest pain. She had had two uncomplicated pregnancies, 35 and 14 years previously, and her menopause had occurred in 1964 with no subsequent bleeding. She gave no history of any operation or serious illness.

INVESTigation A radiograph of the chest (Fig. 1) showed a thin-walled cystic lesion in the right midzone with a little irregularity of the lower wall of the cyst. A tomogram showed the lesion to extend from the $8 \mathrm{~cm}$. to the $11 \mathrm{~cm}$. cut and to have the appearance of a multilocular cyst. The Mantoux test was negative at 1/1,000 O.T. Lung function studies were within normal limits. The vital capacity was 2.551 , F.E.V.1 2.25 1., F.E.V.1/V.C. $88 \%$, and the indirect M.B.C. $83 \mathrm{l} / \mathrm{min}$. The haemoglobin was $13.7 \mathrm{~g} . / 100$ ml. and white cell count $6,400 /$ c.mm. (neutrophils $71 \%$, lymphocytes $28 \%$, monocytes $1 \%$ ). The erythrocyte sedimentation rate was $21 \mathrm{~mm}$./hour (Westergren). No carcinoma cells or acid-fast bacilli were found in the sputum.

On 30 August 1965 a right thoracotomy was performed and a cystic lesion was removed from the posterior region of the upper lobe.

On 12 October 1965 she was referred to a gynaecologist, who found a fibroid tumour of the uterus.

On 3 August 1966 the chest radiograph was normal.

\section{PATHOLOGY}

Gross The specimen was a wedge of lung with pleura on one surface. It measured $2.5 \times 2.3 \mathrm{~cm}$. and contained a collapsed cyst $2 \mathrm{~cm}$. in diameter. The

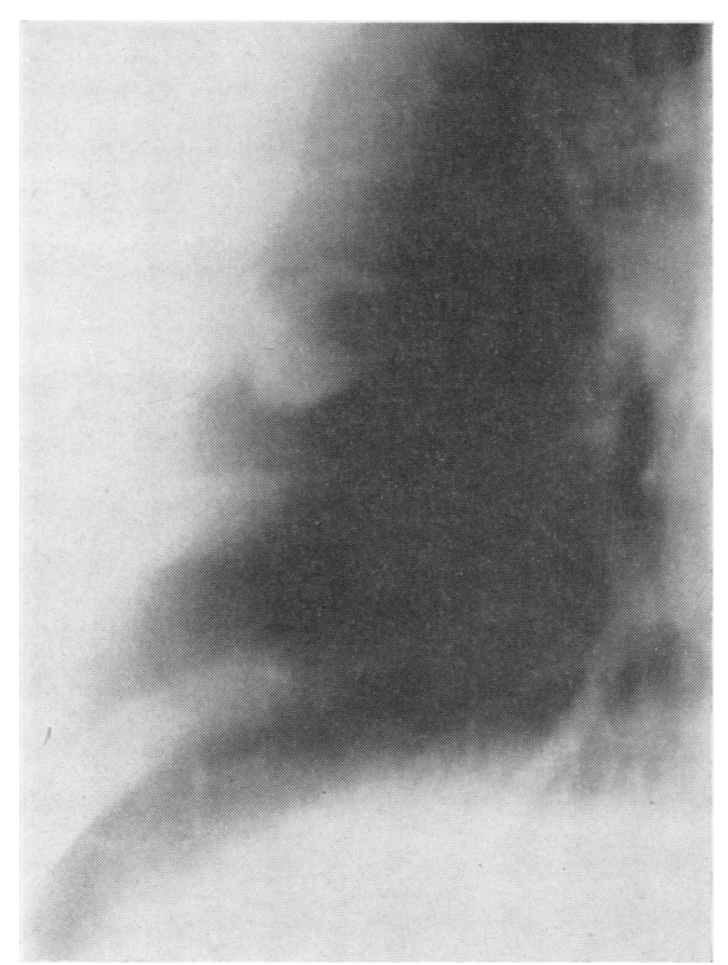

FIG. 1. Tomogram of chest showing a cystic lesion in the right mid-zone. 


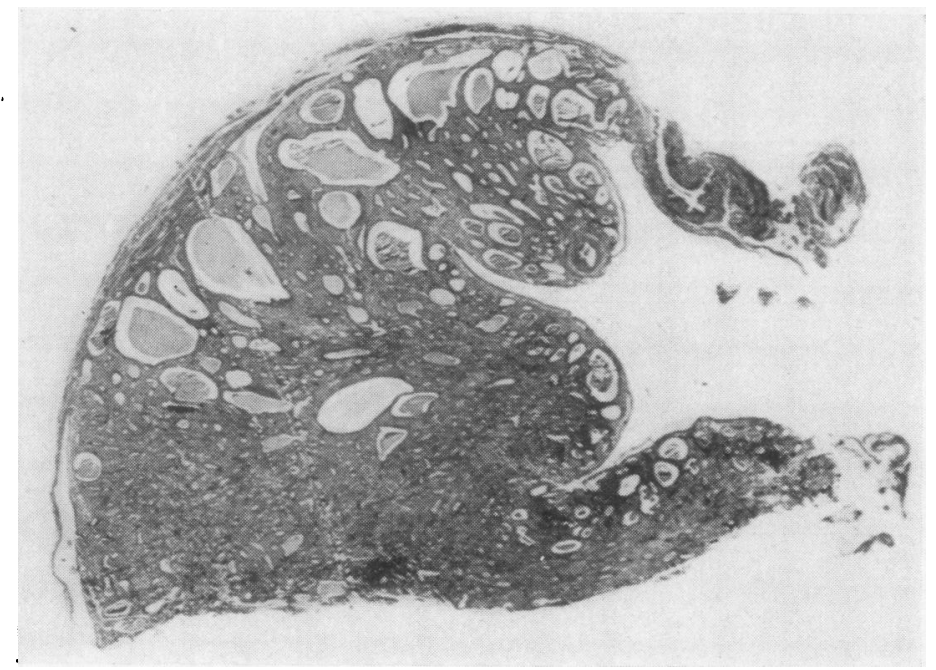

FIG. 2. Subpleural endometrial cyst $(H$. and $E . \quad \times 9)$.

wall of the cyst was thin, but on the side nearest the pleura a polypoid nodule projected into the lumen.

Microscopic (Figs 2 and 3) The lesion was well demarcated but not encapsulated. It lay immediately under the pleura, which was slightly thickened by fibrosis. In the polypoid portion of the lesion there were glandular spaces which varied from small tubules to large dilated cysts and were lined by dark-staining, columnar epithelium with promirent elongated nuclei and occasional wider cells with pale-staining cytoplasm and round nuclei. The stroma was very cellular. It was more fibrous and contained larger blood vessels than does normal endometrial stroma. This and the structure of the glands gave the lesion the appearance of an endometrial polyp. At the tip of the polypoid projection there was a small muscular artery with an internal and an external elastic lamina and a prominent intima. In its thinner portion the cyst wall was lined by a single layer of low columnar to flattened epithelial cells resting upon a loose connective tissue stroma. Unfortunately, the connexion with the bronchus was not demonstrated in the sections, although a large bronchiole was seen immediately outside the cyst wall.
FIG. 3. Part of the polypoid projection showing thick-walled artery ( $H$. and $E . \times 50)$.

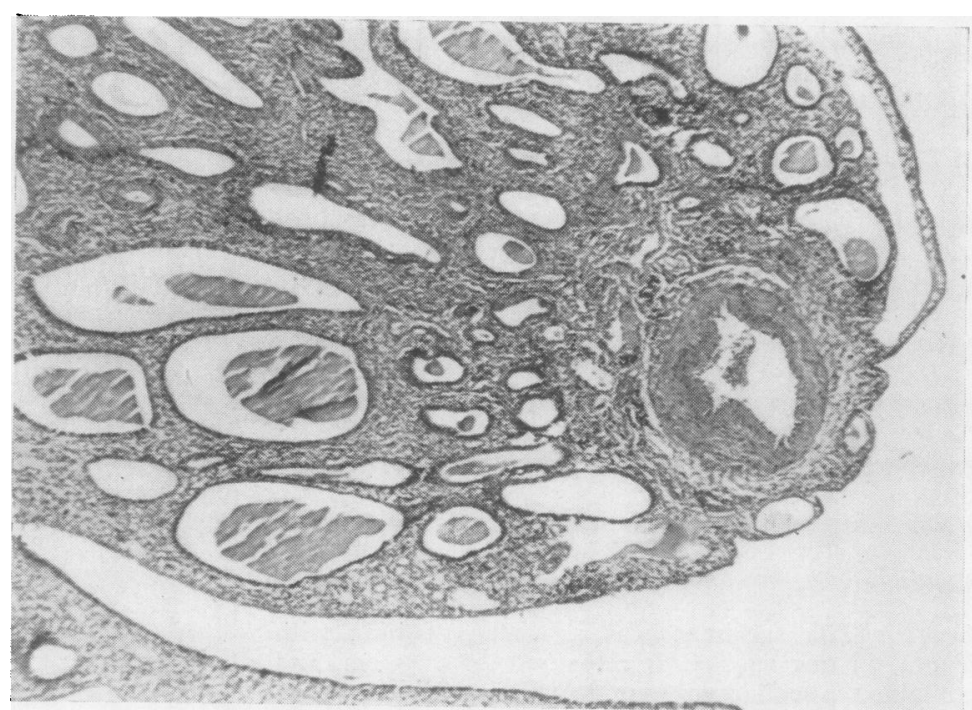


DISCUSSION

This case resembles that described by Sturzenegger (1960) in that the patient was post-menopausal and gave no history of haemoptysis. The absence of haemoptysis in our patient is surprising in view of the large number of vessels and the prominent artery lying immediately under the surface of the polypoid projection.

The theories of pathogenesis have been covered in several previous papers (Hartz, 1956; Lattes, Shepard, Tovell, and Wylie, 1956; Mobbs and Pfanner, 1963 ; Park, 1954). Although pleural endometriosis can be explained by coelomic metaplasia or spread through pleuroperitoneal sinuses, a similar explanation for endometriosis within the lung is more difficult to accept, especially in the presence of a circulation which is known to transport other fragmentary material such as trophoblast. The possibility of vascular spread has been shown experimentally in rabbits by Hobbs and Bortnick (1940) but is more difficult to prove in the human. At least two of the cases listed in Table I (Dr. Godman's case reported by Lattes et al. (1956) and Cameron and Park's first case (1965) ) showed decidual tissue in blood vessels, and in none of these was the decidual tissue in contact with the pleura. It is likely that the lesions were embolic in origin. In the second group, on the other hand, most of the lesions were directly beneath the pleura. The only exception is the case described by Lattes et al. (1956) in which the proximity of the lesion to the pleura was not mentioned, although the illustration of the gross specimen suggests that it may have been. The proximity of the lesions to the pleura makes it difficult to exclude a pleural origin with subsequent growth into the lung substance. If both groups of lesions are embolic in origin, why are there glands in all the larger and probably older lesions (Table II) but not in the small, apparently recent deposits of decidua (Table I) ? In at least three of the cases in the first group (Park, 1954 ; Cameron and Park, 1965), the decidual cells appear to have been growing in the lung parenchyma. Whether they would have persisted after the pregnancy is not known. Neither is it known whether the glands seen in the second group had been transported as glands or whether they appeared later by metaplasia and if so from which cells. Most of the patients in the second group had had previous pregnancies (no history is given in Sturzenegger's case (1960)). If their lung lesions had resulted from metastases during those pregnancies, it would be interesting to know whether cells other than differentiated decidual cells were present in the emboli.

We are very grateful to Dr. V. J. McGovern, Director of Fairfax Institute of Pathology, Royal Prince Alfred Hospital, for his help in the preparation of this paper.

\section{REFERENCES}

Cameron, H. M., and Park, W. W. (1965). Decidual tissue within the lung. J. Obstet. Gynaec. Brit. Cwlth, 72, 748.

Hartz, P. H. (1956). Occurrence of decidua-like tissue in the lung. Report of a case. Amer. J. clin. Path., 26, 48.

Hobbs, J. E., and Bortnick, A. R. (1940). Endometriosis of the lung; an experimental and clinical study. Amer. J. Obstet. Gynec., 40, 832.

Kovarik, J. L., and Toll, G. D. (1966). Thoracic endometriosis with recurrent spontaneous pneumothorax. J. Amer. med. Ass., 196, 595.

Lattes, R., Shepard, F., Tovell, H., and Wylie, R. (1956). A clinical and pathologic study of endometriosis of the lung. Surg. Gynec. Obstet., 103, 552.

Mobbs, G. A., and Pfanner, D. W. (1963). Endometriosis of the lung. Lancet, 1, 472.

Park, W. W. (1954). The occurrence of decidual tissue within the lung: report of a case. J. Path. Bact., 67, 563.

Rodman, M. H., and Jones, C. W. (1962). Catamenial hemoptysis due to bronchial endometriosis. New Engl. J. Med., 266, 805.

Sturzenegger, H. (1960). Lungenendometriose unter dem Bild des Rundschattens. Schweiz. Z. Tuberk., 17, 259. 